\title{
GMR
}

\section{Effect of compound Maqin decoction on TGF- $\beta 1 /$ Smad proteins and IL-10 and IL-17 content in lung tissue of asthmatic rats}

\author{
Y.H. Xie, X.P. Li, Z.X. Xu, P. Qian, X.L. Li and Y.Q. Wang \\ Staff Room of Diagnosis, Basic Medicine College, \\ Shanghai University of Traditional Chinese Medicine, Shanghai, China \\ Corresponding author: Z.X. Xu \\ E-mail: zhaoxia7001@126.com
}

Genet. Mol. Res. 15 (3): gmr.15037539

Received August 27, 2015

Accepted December 7, 2015

Published September 2, 2016

DOI http://dx.doi.org/10.4238/gmr.15037539

Copyright (C) 2016 The Authors. This is an open-access article distributed under the terms of the Creative Commons Attribution ShareAlike (CC BY-SA) 4.0 License.

\begin{abstract}
In this research, compound Maqin decoction (CMD) has been shown to positively affect in airway inflammation of asthma models. We evaluated the effects of CMD on the expression of transforming growth factor (TGF)- $\beta 1 / \mathrm{Smad}$ proteins, interleukin (IL)-17, and IL-10 in lung tissue of asthmatic rats. Asthma was induced in a rat model using ovalbumin. After a 4-week treatment with CMD, rats were killed to evaluate the expression of TGF- $\beta 1$ and Smad proteins in lung tissue. IL-10 and IL-17 levels in lung tissue homogenates were determined by ELISA. The expression of TGF- $\beta 1$ and Smad3 protein increased, whereas expression of Smad7 protein decreased upon high-dose or low-dose treatment with CMD or by intervention with dexamethasone, compared to the control. There was a significant difference between treatment with a high dose CMD and the control treatment, but no significant difference was found between high-dose CMD treatment and dexamethasone intervention.
\end{abstract}

Genetics and Molecular Research 15 (3): gmr.15037539 
The expression of TGF- $\beta 1$ and Smad7 protein increased, whereas the expression of Smad3 protein decreased in the model group compared to other groups. In the CMD high-dose group, low-dose group, and dexamethasone intervention group, the IL-17 concentrations in lung tissue homogenates were decreased, while IL-10 levels were increased. Again, there was a significant difference between CMD high-dose and control treatment, but not between CMD high-dose treatment and dexamethasone intervention. Thus, positive effects of CMD against asthmatic airway remodeling may be due to its regulatory effect on TGF- $\beta 1$, Smad3, and Smad7 protein levels and on cytokines such as IL-10 and IL-17.

Key words: Asthma; TGF- $\beta$; Smad protein; IL-10; IL-17

\section{INTRODUCTION}

The pathogenic mechanisms of asthma have not been fully elucidated. Research has shown that transforming growth factor (TGF)- $\beta 1$ is involved in injury repair after epithelial inflammation and airway remodeling (Bossé and Rola-Pleszczynski, 2007; Torrego et al., 2007; Fattouh and Jordana, 2008). Drosophila mothers against decapentaplegic (SMAD) is a family of proteins similar to the gene products of the Drosophila gene (Mad) and the Caenorhabditis elegans gene Sma. SMADs are signal transduction proteins that act downstream of TGF- $\beta$ and play important roles in airway remodeling and asthma. Interleukin (IL)-10 is an immunosuppressive factor secreted by regulatory $\mathrm{T}$ cells (Tregs) that inhibits the production of pro-inflammatory cytokines and chemokines in T cells and eosinophils (Zheng et al., 2004). IL-17, a proinflammatory cytokine produced by T-helper (Th) 17 cells and eosinophils, aggravates airway inflammation and participates in airway remodeling, and thus plays a negative regulatory role in asthma (An et al., 2012).

Compound Maqin decoction (CMD) is a recipe of Chinese herbs that has been used by our research team for 20 years. Clinical studies have shown that CMD can regulate immune function, inhibit the inflammatory response, and relax bronchial smooth muscle (Wang et al., 2003, 2006; Teng et al., 2008). In addition, CMD can significantly inhibit airway inflammation in asthmatic guinea pigs, thereby improving lung function.

In the present study, we assessed the expression of TGF- $\beta 1 /$ Smad proteins, IL-10, and IL-17 in lung tissue during airway remodeling in asthmatic rats. We evaluated the effects of CMD on these factors to investigate its mechanism of action in the treatment of asthma.

\section{MATERIAL AND METHODS}

\section{Animals}

Fifty male Sprague Dawley rats (200 \pm 20 g; Shanghai Silaike Experimental Animals, Shanghai, China) were divided randomly into five groups of 10: control, model, dexamethasone intervention, CMD high dose, and CMD low dose.

Genetics and Molecular Research 15 (3): gmr.15037539 


\section{Reagents and instruments}

Assay kits for 3,3'-diaminobenzidine (DAB), streptavidin-biotin complex, and goat anti-rabbit IgG were purchased from Wuhan Boster Biological Engineering (Wuhan, China). A 1 x 71 Microscope plus image analysis system (Olympus, Tokyo, Japan) was used. An enzyme-linked immunosorbent assay (ELISA) kit was purchased from Shanghai Shirui Pharmaceuticals (Shanghai, China).

\section{Establishment of an animal model of asthma}

A rat model of asthma was established based on a previously described method (Waserman et al., 1992; Xu et al., 2006). On day 1 and 7, all rats, except for those in the control group, were intraperitoneally injected with $1 \mathrm{~mL}$ of a solution containing $100 \mathrm{mg}$ ovalbumin (OVA) and $100 \mathrm{mg}$ aluminum hydroxide. On day 15 , asthma was induced in rats by $1 \%$ OVA inhalation at $40 \mathrm{~mL}$ for $20 \mathrm{~min}$ each day for 28 successive days. Rats in the control group were injected and subjected to inhalation with physiologic $(0.9 \%)$ saline instead of OVA at identical time points.

\section{Drug intervention}

Dexamethasone tablets (Shanghai Xinyi Pharmaceuticals, Shanghai, China) were processed to a $0.32 \mathrm{mg} / \mathrm{mL}$ suspension in $0.9 \%$ saline. For the preparation of CMD, $9 \mathrm{~g}$ baikal skullcap root, Siberian cocklebur fruit, common Nandina, winter sweet flowers and Elaeagnus leaves, as well as $4 \mathrm{~g}$ processed ephedra, were soaked in water for $1 \mathrm{~h}$. For the first decoctum, the volume of water was 10 times that of the total amount of herbs. For the second decoctum, the volume of water was 4 times that of the total amount of herbs. The decoction liquid was extracted from the gruffs and concentrated by evaporation into a solution with a crude drug concentration of $1 \mathrm{~g} / \mathrm{mL}$. The high dose group was treated with a $1 \mathrm{~g} / \mathrm{mL}$ solution, while for the low-dose group a $0.5 \mathrm{~g} / \mathrm{mL}$ solution was used.

Starting on day 1 of asthma induction, the rats in control and model groups received $0.9 \%$ saline via intragastric delivery once a day. Rats in the other groups were also treated daily with either dexamethasone suspension (dexamethasone intervention group), $1 \mathrm{~g} / \mathrm{mL}$ CMD (high-dose group), or $0.5 \mathrm{~g} / \mathrm{mL}$ CMD (low-dose group). The lavage dose was $10 \mathrm{~mL} / \mathrm{kg}$ body weight in all groups. After 4 weeks of treatment, the rats were killed and samples were harvested to measure the relevant study parameters.

\section{Collection and preparation of specimens}

Rat lungs were exposed by thoracotomy. Tissue from the right lung was immersed in $4 \%$ paraformaldehyde solution and fixed for $24 \mathrm{~h}$, cut into 3-mm thick slices, and fixed in $4 \%$ paraformaldehyde for $72 \mathrm{~h}$. After addition of ethanol for graded dehydration and xylene for transparency, slices were paraffin-embedded and prepared into serial sections of $6 \mu \mathrm{m}$ for immunohistochemical (IHC) analysis.

Next, lung tissue homogenates were prepared. Briefly, 0.2-1 g lung tissue was rinsed with cold $0.9 \%$ saline to remove blood. While, a total volume of cold saline $(0.86 \%)$ of 9 times the weight of the lung tissue was used, two-thirds of the saline was removed and placed

Genetics and Molecular Research 15 (3): gmr.15037539 
in a beaker with a pipette. Blocks of lung tissue were minced rapidly and placed into a glass homogenizer. The remaining one-third of saline was used to cleanse the residual tissues in the beaker. Residual tissues were then poured into the homogenizer. Ten percent of the prepared homogenate was centrifuged at approximately $3000 \mathrm{rpm}$ for $10 \mathrm{~min}$. The homogenate was preserved and the supernatant was used for ELISA.

\section{Immunohistochemistry}

Sections of bronchopulmonary tissue were used for IHC following the kit instructions. Sections were sliced, dewaxed, and dehydrated. Next, they were blocked with 3\% hydrogen peroxide for $10 \mathrm{~min}$, immersed in citric acid, and heated in a microwave. Sections were incubated with goat serum for 20 min and subsequently with the first antibody (anti-TGF- $\beta 1$, anti-Smad3, and anti-Smad7, Wuhan Yi-Thai Technology Co., Ltd.) overnight at $4^{\circ} \mathrm{C}$. Biotinylated secondary antibody was added for a 30 -min incubation at $37^{\circ} \mathrm{C}$. SABC reagent was added for $30 \mathrm{~min}$ at $37^{\circ} \mathrm{C}$ and $\mathrm{DAB}$ staining was then initiated, followed by hematoxylin counterstaining for $30 \mathrm{~s}$. Standard procedures were then followed for signal detection and analysis under a microscope.

\section{Quantification}

In all groups of lung tissue sections, IHC staining for TGF- $\beta 1$, Smad7 and Smad3 protein was performed and scored as positive for TGF- $\beta 1$, Smad3, or Smad7. Positive expression was mainly detected in airway epithelial cells, in cells beneath mucous membranes, and in the smooth muscle layer. Gray areas were measured using the image analysis software, and the relative area positive for protein expression was calculated.

For the ELISA, the optical density (OD) value was determined within 15 min after addition of stopping buffer at $450 \mathrm{~nm}$ in a Microplate Reader, for a total of 4 times at an interval of $3 \mathrm{~min}$, to obtain more accurate data. The mean OD value was calculated. Using SPSS v18.0 (SPSS, Armonk, NY, USA), a standard curve $\left(\mathrm{R}_{2} \geq 0.99\right)$ was drawn by which the concentrations of IL-10 and IL-17 in the lung tissue homogenate of each rat were calculated.

\section{Statistical analyses}

Data are reported as means \pm standard deviation. Differences between groups were analyzed by ANOVA with $\alpha=0.05$. P $<0.05$ was considered statistically significant. SPSS v18.0 was used for all analyses.

\section{RESULTS}

\section{TGF-ß1, Smad3, and Smad7 protein expression in lung tissue sections of rats}

The expression of TGF- $\beta 1$ and Smad7 proteins in lung tissue was significantly increased in all groups compared with the control group, whereas the expression of Smad3 was significantly decreased (Table 1). In comparison to the model group, the expression of TGF- $\beta 1$ and Smad7 protein was significantly increased upon treatment with a high dose of $\mathrm{CMD}$, while the expression of Smad3 was significantly decreased. 
Table 1. Relative expression of TGF- $\beta 1, \mathrm{Smad} 3$, and $\mathrm{Smad} 7$ in lung tissue (means $\pm \mathrm{SD}$ ).

\begin{tabular}{l|c|c|c|c}
\hline Group & $\mathrm{N}$ & TGF- $\beta 1$ & Smad7 & Smad3 \\
\hline Control & 8 & $0.0601 \pm 0.0163$ & $0.0303 \pm 0.0112$ & $0.1325 \pm 0.0401$ \\
\hline Model & 8 & $0.1033 \pm 0.0164 *$ & $0.0900 \pm 0.0264 *$ & $0.0737 \pm 0.0207 *$ \\
\hline Dexamethasone & 8 & $0.0986 \pm 0.0126 *$ & $0.0647 \pm 0.0341 *^{+}$ & $0.0814 \pm 0.0213 *$ \\
\hline CMD high & 8 & $0.0910 \pm 0.0155 *^{+}$ & $0.0600 \pm 0.0157 *^{+}$ & $0.0948 \pm 0.01723 *^{+}$ \\
\hline CMD low & 8 & $0.0976 \pm 0.0126 *$ & $0.0747 \pm 0.0253 *$ & $0.0837 \pm 0.0229 *$ \\
\hline
\end{tabular}

${ }^{*} \mathrm{P}<0.05$ compared with the control group. ${ }^{+} \mathrm{P}<0.05$ compared with the model group.

\section{IL-10 and IL-17 expression in rat lung tissue homogenates}

IL-10 levels were significantly increased and IL-17 levels significantly decreased in lung tissue homogenates from all groups, compared to the control group (Table 2). There was a significant difference between the control group and the model group, the dexamethasone intervention, and the CMD low-dose groups, but no significant difference was observed between the control group and the CMD high-dose group. IL-10 levels were also increased and IL-17 levels decreased in lung tissue homogenates in the CMD high-dose, CMD lowdose, and dexamethasone intervention groups, compared to the model group. There was a significant difference between the CMD high-dose group and the model group. No significant differences were observed between the CMD high-dose, CMD low-dose, and dexamethasone intervention groups.

Table 2. IL-10 and IL-17 expression in lung tissue homogenates (means $\pm \mathrm{SD}$ ).

\begin{tabular}{l|c|c|c}
\hline Group & $\mathrm{N}$ & $\mathrm{IL}-10(\mathrm{ng} / \mathrm{mL})$ & $\mathrm{IL}-17(\mathrm{ng} / \mathrm{mL})$ \\
\hline Control & 8 & $0.0011 \pm 0.0003$ & $0.0008 \pm 0.0002$ \\
\hline Model & 8 & $0.0073 \pm 0.0003 *$ & $0.0013 \pm 0.0002 *$ \\
\hline Dexamethasone & 8 & $0.0009 \pm 0.0002 *$ & $0.0011 \pm 0.0002 *$ \\
\hline CMD high & 8 & $0.0010 \pm 0.0002^{+}$ & $0.0010 \pm 0.0002^{+}$ \\
\hline CMD low & 8 & $0.0008 \pm 0.0001 *$ & $0.0010 \pm 0.0003 *^{+}$ \\
\hline
\end{tabular}

$* \mathrm{P}<0.05$ compared with the control group. ${ }^{+} \mathrm{P}<0.05$ compared with the model group.

\section{DISCUSSION}

Airway remodeling is the major pathologic cause of irreversible airway obstruction and airway hyper-responsiveness. It is closely correlated with the duration, severity, prognosis, and treatment response of asthma.

TGF- $\beta$ is a multifunctional regulator directly involved in airway inflammation and remodeling through the promotion of inflammatory cell differentiation and proliferation, the aggravation of hyperplasia and hypertrophy of smooth muscle and of damage to epithelial cells, and the facilitation of smooth muscle cell and fibroblast proliferation (Moir et al., 2008; Moore et al., 2008). As specific intracellular signal transduction molecules in the TGF- $\beta$ family, Smads play important roles in the maintenance of physiological cell functions. Smad3 is essential in signal transposition into the nucleus for all TGF- $\beta$ family members. Smad 7 can be combined with the activated type-I receptor to repress signal transduction in the TGF- $\beta$ family. The TGF- $\beta /$ Smad signaling pathway is important for the biological function of TGF- $\beta$. Active TGF- $\beta 1$ can bind and activate type I/II TGF- $\beta$ receptors (Turner et al., 2008; Zhao et al.,

Genetics and Molecular Research 15 (3): gmr.15037539 
2008).The activated receptor in turn activates $\mathrm{Smad} 3$ and Smad4, and together they aggregate into a common complex or form several heterodimers. This complex enters the nucleus and combines with specific target DNA sequences to trigger gene transcription, thereby causing proliferation and phenotypic transformation of smooth muscle cells in airways and vessels.

IL-10 is an immunosuppressive factor secreted by Tregs. It inhibits $\mathrm{T}$ cells and eosinophils from producing pro-inflammatory cytokines and chemokines (Zheng et al., 2004), and prevents activation of T-cell receptor-mediated $\mathrm{CD} 4^{+} \mathrm{T}$ cells. Treatment with IL-10 can lead to a long-lasting inhibition of antigen-specific T cells (Bellinghausen et al., 2001), and thus IL10 has anti-inflammatory activity. IL-17 is a pro-inflammatory cytokine secreted by Th17 cells and eosinophils that exacerbates airway inflammation, participates in airway remodeling, and has a negative regulatory role in asthma (An et al., 2012). IL-17 acts on eosinophils, causing the release of a large number of cytokines and chemical mediators (Cheung et al., 2008).

Our previous study clearly showed that CMD relieves symptoms and improves lung function in patients with asthma (Wang et al., 2006). The present study shows that CMD can regulate the expression of TGF- $\beta 1, \mathrm{Smad} 3$, and Smad7. Compared with the model group, the relative expression of TGF- $\beta 1$ and Smad7 was significantly increased, whereas the relative expression of Smad3 was significantly decreased in rat long tissue of the CMD high-dose group. The present study also showed that CMD treatment affects the concentrations of IL10 and IL-17 in lung tissue homogenates. In the CMD treatment groups, IL-10 levels were increased and IL-17 levels were decreased. There was a significant difference between the high-dose group and the model group. Asthma can be treated with traditional Chinese medicine, which may be explained by its regulatory effect on TGF- $\beta 1, \mathrm{Smad} 3$, and Smad7 in lung tissue and on cytokines such as IL-10 and IL-17.

\section{Conflicts of Interest}

The authors declare no conflict of interest.

\section{ACKNOWLEDGMENTS}

Research supported by the Shanghai Natural Science Foundation (\#14ZR441500) and the Shanghai TCM Special Funds Project of Health and Family Planning (\#2014JP029A).

\section{REFERENCES}

An X, Gong Y, Ye L and Jin ML (2012). Advance on studies of T helper 17 cells and its relative cytokines and bronchial asthma. Chin. J. Asthma 1: 26-29.

Bellinghausen I, Knop J and Saloga J (2001). The role of interleukin 10 in the regulation of allergic immune responses. Int. Arch. Allergy Immunol. 126: 97-101. http://dx.doi.org/10.1159/000049499

Bossé Y and Rola-Pleszczynski M (2007). Controversy surrounding the increased expression of TGF $\beta 1$ in asthma. Respir. Res. 8: 66-83. http://dx.doi.org/10.1186/1465-9921-8-66

Cheung PF, Wong CK and Lam CW (2008). Molecular mechanisms of cytokine and chemokine release from eosinophils activated by IL-17A, IL-17F, and IL-23: implication for Th17 lymphocytes-mediated allergic inflammation. $J$. Immunol. 180: 5625-5635.http://dx.doi.org/10.4049/jimmunol.180.8.5625

Fattouh R and Jordana M (2008). TGF- $\beta$, eosinophils and IL-13 in allergic airway remodeling: a critical appraisal with therapeutic considerations. Inflamm. Allergy Drug Targets 7:224-236.http://dx.doi.org/10.2174/187152808786848388

Moir LM, Burgess JK and Black JL (2008). Transforming growth factor beta 1 increases fibronectin deposition through integrin receptor alpha 5 beta 1 on human airway smooth muscle. J. Allergy Clin. Immunol. 121: 1034-9.e4.http:// dx.doi.org/10.1016/j.jaci.2007.12.1159

Genetics and Molecular Research 15 (3): gmr.15037539 
Moore B, Murphy RF and Agrawal DK (2008). Interaction of tgf-beta with immune cells in airway disease. Curr. Mol. Med. 8: 427-436. http://dx.doi.org/10.2174/156652408785160943

Teng Z, Wang Y, Li F, Yan H, et al. (2008). Tracheal compliance and limit flow rate changes in a murine model of asthma. Sci. China C Life Sci. 51: 922-931.http://dx.doi.org/10.1007/s11427-008-0108-7

Torrego A, Hew M, Oates T, Sukkar M, et al. (2007). Expression and activation of TGF-beta isoforms in acute allergeninduced remodelling in asthma. Thorax 62: 307-313.http://dx.doi.org/10.1136/thx.2006.063487

Turner NJ, Jones HS, Davies JE and Canfield AE (2008). Cyclic stretch-induced TGFbeta1/Smad signaling inhibits adipogenesis in umbilical cord progenitor cells. Biochem. Biophys. Res. Commun. 377: 1147-1151. http://dx.doi. org/10.1016/j.bbrc.2008.10.131

Wang YQ, Li FF, Teng ZZ, Li BF, et al. (2003). Research of the airway reconstruction characteristics in bronchial asthmatic rats. Chin. J. Tuberc. Respir. Dis. 11: 728-729.

Wang YQ, Li FF, Yan HX, Zhang XY, et al. (2006). Combination Ephedra and Scutellaria Decoction Regulates Immune Function of Child with Asthma. J Shanghai Tradi Chin Med. 4: 37-38.

Waserman S, Olivenstein R, Renzi P, Xu LJ, et al. (1992). The relationship between late asthmatic responses and antigenspecific immunoglobulin. J. Allergy Clin. Immunol. 90: 661-669. http://dx.doi.org/10.1016/0091-6749(92)90140-W

Xu SY, Xu YJ, Zhang ZX, Ni W, et al. (2006). Pathological features and mechanisms of airway remodeling in asthmatic rats. Acta Med. Univ. Sci. Technol. Huazhong 4: 465-472.

Zhao W, Gomez G, Yu SH, Ryan JJ, et al. (2008). TGF-beta1 attenuates mediator release and de novo Kit expression by human skin mast cells through a Smad-dependent pathway. J. Immunol. 181: 7263-7272. http://dx.doi.org/10.4049/ jimmunol.181.10.7263

Zheng SG, Wang JH, Gray JD, Soucier H, et al. (2004). Natural and induced CD4+CD25+ cells educate CD4+CD25- cells to develop suppressive activity: the role of IL-2, TGF-beta, and IL-10. J. Immunol. 172: 5213-5221. http://dx.doi. org/10.4049/jimmunol.172.9.5213

Genetics and Molecular Research 15 (3): gmr.15037539 